
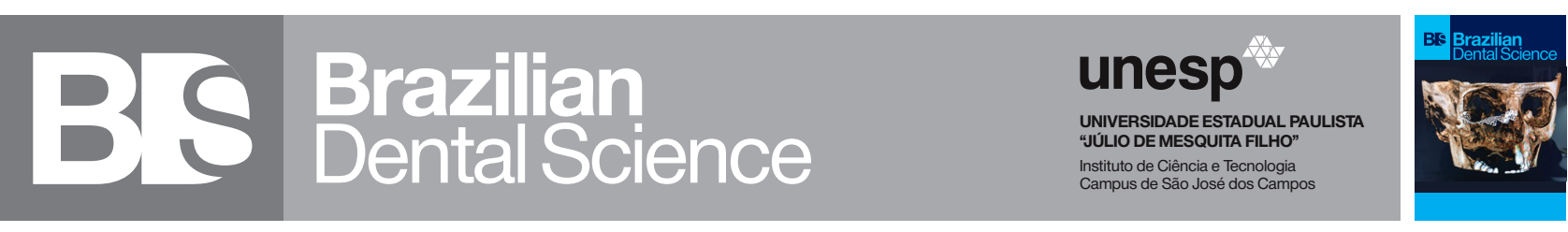

\title{
Overdenture on dental remaining in oncological patients: case report
}

\author{
Overdenture sobre remanescente dental em paciente oncológico: relato de caso
}

Victoria Garcia de CARVALHO ${ }^{1}$, Cláudio MOREIRA JÚNIOR ${ }^{1}$, Lucio Murilo dos SANTOS ${ }^{2}$, Tarcísio José de Arruda PAES JÚNIOR ${ }^{3}$

1 - São Paulo State University (Unesp) - Institute of Science and Technology, São José dos Campos - Department of Restorative Dentistry - Operative Dentistry Division - São José dos Campos - SP - Brazil

2 - São Paulo State University (Unesp) - Institute of Science and Technology, São José dos Campos - Department of Biosciences and Oral Diagnosis - São José dos Campos - SP - Brazil

3 - São Paulo State University (Unesp) - Institute of Science and Technology, São José dos Campos - Department of Dental Materials and Prosthodontics - São José dos Campos - SP - Brazil

\section{ABSTRACT}

Head and neck cancer occupy the seventh place among the most common neoplasms in the world, with an annual incidence of approximately 640,000 new cases. Radiotherapy treatment has been highlighted, because there is greater tissue preservation, possibility of regression of the disease, decreased tumor volume, prevention of possible tumor recurrences and metastases, and even total cancer cure, but patients undergoing radiotherapy are at high risk of osteoradionecrosis if they perform surgical interventions in the region, such as dental implants and dental extraction, making prosthetic rehabilitation of partially edentulous patients after treating oral cancer something complex and often omitted; although it is a crucial factor in restoring oral function. Thus, the aim of the present study was to describe the planning, treatment and follow-up of a twelve-month prosthetic approach to rehabilitate the lower arch shape and function of a partially edentulous patient undergoing head and neck radiotherapy with a full denture mucus supported and tooth retained. After twelve months of follow-up, it was possible to evidence the functional and aesthetic clinical success, with preserved occlusal pattern, soft and bone tissue around and dental roots.

\section{KEYWORDS}

Radiotherapy; Head and Neck Neoplasms; Overdentures; Oral Rehabilitation.

\section{RESUMO}

O câncer de cabeça e pescoço ocupa o sétimo lugar entre as neoplasias mais comuns do mundo, com uma incidência anual de aproximadamente 640.000 novos casos. O tratamento com radioterapia tem se destacado, pois há maior preservação tecidual, possibilidade de regressão da doença, diminuição do volume tumoral, prevenção de possíveis recorrências e metástases tumorais e até cura total do câncer, mas os pacientes submetidos à radioterapia apresentam alto risco de osteorradionecrose se realizar intervenções cirúrgicas na região, como implantes dentários e extração dentária, fazendo com que a reabilitação protética, de pacientes parcialmente dentados depois de tratar o câncer bucal, algo complexo e frequentemente omitido; embora seja um fator crucial para o reestabelecimento da função oral. Assim, o objetivo do presente estudo foi descrever o planejamento, tratamento e acompanhamento de doze meses de uma abordagem protética para reabilitar forma e função do arco inferior de um paciente parcialmente desdentado, submetido a radioterapia de cabeça e pescoço, com o uso de uma prótese total mucossuportada e dente retida. Após doze meses de acompanhamento, foi possível evidenciar o sucesso clínico funcional e estético, com padrão oclusal, rebordo alveolar e remanescentes dentários preservados.

\section{PALAVRAS-CHAVE}

Radioterapia; Câncer de Cabeça e Pescoço; Overdentures; Reabilitação Oral. 


\section{INTRODUCTION}

$\mathrm{H}$ ead and neck cancer rank seventh among the most common cancers in the world, with an annual incidence of approximately 640,000 new cases $[1,2]$. Its treatment depends on factors such as cancer type, staging, location, and may be performed by surgery, radiotherapy, chemotherapy or a combination of these [2]. The radiotherapy method has been highlighted because there is greater preservation of structures [3,4], possibility of disease regression, reduction of tumor volume, prevention of possible tumor recurrences and metastases, and even total cure [5].

Cancer patients tend to have a high prevalence of oral problems, either due to the side effects of the imposed treatments, or the general health conditions that may influence [6, 7], and the prosthetic rehabilitation of partially edentulous patients after the oral cancer treatments complex and often overlooked; although it is a crucial factor for such patients to restore oral and aesthetic functions [8].

The total overdenture prosthesis is a more comfortable and conservative solution for these patients, offering advantages over conventional prostheses, being more stable, functional, able to promote better chewing function [9], and partial proprioceptive capacity that would otherwise be lost with conventional total denture treatment [10].

This treatment option is interesting for complex patients such as those undergoing head and neck radiotherapy, considering the general contraindication to surgical procedures and involving any type of bone remodeling in the region, due to the inherent risk of osteoradionecrosis [11]. However, there are no case reports in the literature about prosthetic rehabilitation with overdentures in patients after cancer treatment.
Thus, the aim of this study was to describe the treatment and rehabilitation prosthetic follow-up with overdenture prosthesis in a patient who underwent head and neck radiation, with clinical follow-up of 12 months.

\section{CASE REPORT}

A 67-year-old male patient, upper and lower partial toothless, enrolled the "Onco Project" dental care clinic for cancer patients, at the Science and Technology Institute - ICT UNESP, São José dos Campos - Brazil campus, for dental rehabilitation of the lower arch. In his medical history, the patient reported being HIV positive and diagnosed with vocal cord squamous cell carcinoma in 2008, which was treated by 35 radiotherapy sessions. After this, the patient was also diagnosed with prostate cancer, which was treated surgically showing good current health.

The patient came to with two provisional removable partial prosthesis in upper and lower jaws, installed 3 years ago (figure 1a), which was indicated for replacement considering its preservation state. His main complaint was the compromised aesthetics, and the difficulty of chewing with the inferior prosthesis.

Intraoral examination revealed preserved mandibular bone tissue and healthy gingival tissue. Only elements \#22 and \#27 were present in the lower arch, both with accentuated gingival recession, slight signs of gingival inflammation, but without signs of mobility, periodontal disease, periodontal pockets, primary and/or secondary caries (figure $1 \mathrm{~b}$ ). On radiographic examination both elements showed adequate bone support around the roots, without signs of pulp or periodontal disease. 


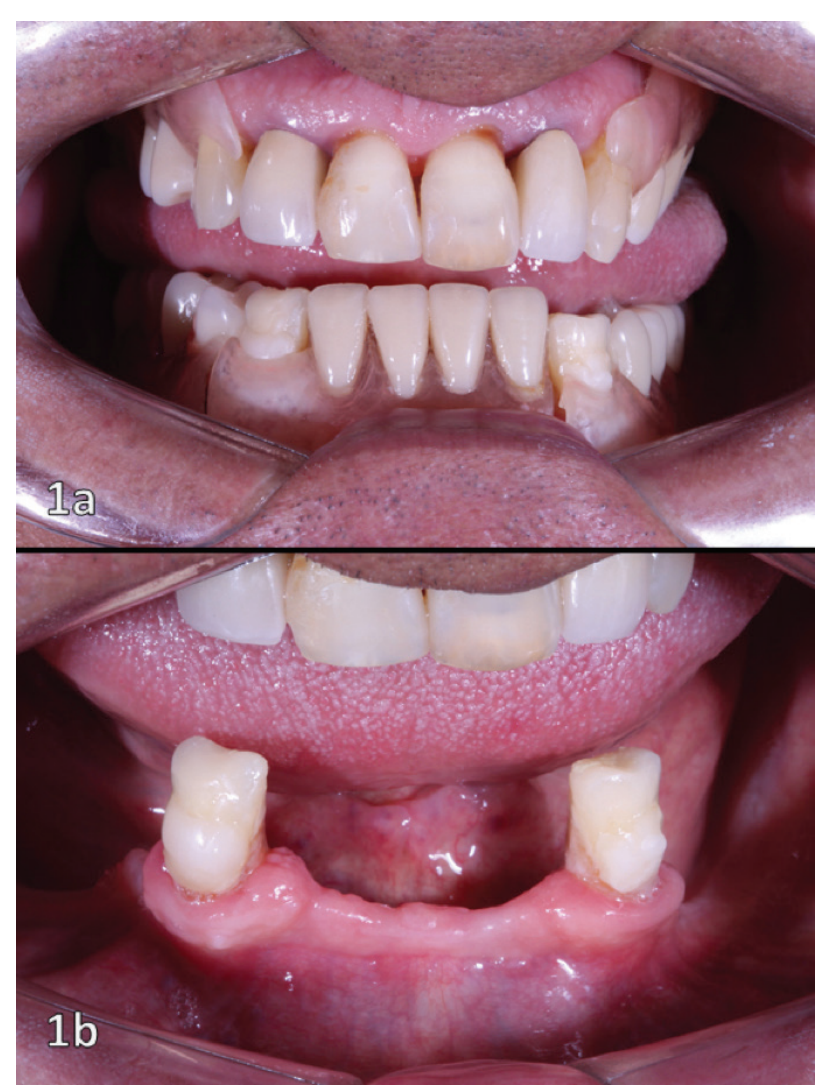

Figure 1 - 1a: Initial appearance with temporary prostheses. 1b: Initial appearance of the elements.

Due to the patient's medical history and associated risks of osteoradionecrosis in case of bone manipulation [11], the possibility of dental extractions or dental implants was rejected, as well as the option of removable partial dentures considering the unfavorable biomechanics and the aesthetics required by the patient. Therefore, the treatment option was total inferior rehabilitation with overdenture over elements \#22 and \#27, using them as prosthetic abutments.

Alginate impressions (Jeltrate Dustless, Dentsply, Pirassununga, SP, Brasil) were performed and plaster models were obtained to study the case; and impressions of the crowns of teeth \#22 and \#27 were performed with silicone material (Optosil, Heraeus Kulzer, São Paulo, Brazil) for subsequent confection of temporary crowns, as well as initial periapical radiographs of elements \#22 and \#27 for planning endodontic treatment.
Endodontic treatment of elements \#22 and \#27 was performed, and dental preparations for future intra-root retainers using \#4138 diamond burs (KG Sorensen, São Paulo, Brazil). Both elements had their filling material removed, until $4 \mathrm{~mm}$ remained in their apical portions, obtaining smooth and divergent internal walls, with opening diameter being one third of the diameter of the root remnant. Then, the coronary remnant (cervical portion) was prepared with \#4138 and \#4138F diamond burs to obtain a chamfered finish. Subsequently, temporary crowns were made using the dense mass condensation silicone pre-molding technique (Optosil, Heraeus Kulzer, São Paulo, Brazil) in self-curing acrylic resin (Dencôr, Classic, Campo Limpo Paulista, SP, Brazil).

The Centric Relation was registered, considering the loss of vertical dimension due to the lack of posterior and anterior occlusal support. For this, an acrylic experimental base was made on working models with thermoplasticized wax patterns used to obtain the vertical occlusion dimension, through phonetic and aesthetic analysis.

Obtaining the ideal vertical dimension of occlusion with the wax rollers, the facial arch was taken using the old upper prosthesis and mounted on a semi-adjustable articulator (Articulator 4000S, BioArt, São Paulo, Brazil).

Functional condensation silicone molding (Optosil and Xantopren, Heraeus Kulzer, Sao Paulo, Brazil) was then performed on stock trays by inserting the light molding material into the root canals, using elastomeric syringes (figure 2a). A functional type IV plaster model was made (Dent-Mix, Asfer, São Caetano do Sul, SP, Brazil), and the lower model was assembled in articulator in the maxillary mandibular position of Central Relations. Subsequently, the $\mathrm{NiCr}$ (Nickel Chromium) alloy intraradicular metal retainers with ball-shaped o'ring system were cast, which would serve to retain the new overdenture prosthesis (figures $2 \mathrm{~b}$ and $2 \mathrm{c}$ ). 


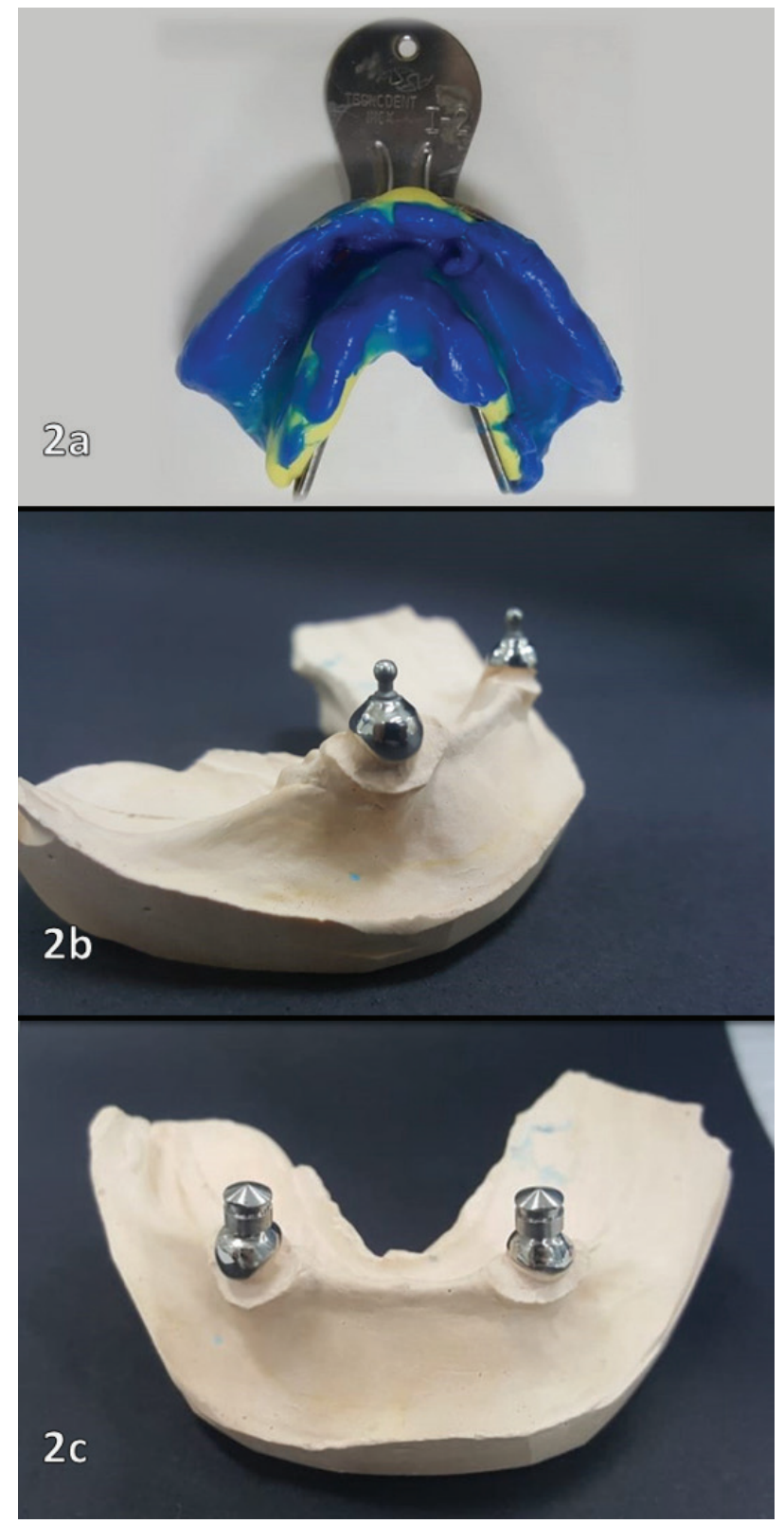

Figure 2 - Lower functional molding. 2b: Plaster model with metal retainers. 2c: Plaster model with metal retainers and fittings.

After that, the artificial teeth were assembled in the wax roller on a test base, aesthetic and functional tests of the teeth, occlusal analysis and adjustments were made and sent for acrylization taking into consideration the positioning of the o'rings systems (figure $3 a)$. With the new acrylic prosthesis, reliefs were performed in the internal region (figure $3 \mathrm{~b}$ ) over the dental remnants so that the o-ring caps retainers could freely occupy the internal space, and it was possible to capture this capsule inside the prosthesis base by using self-curing acrylic resin inserted with Nealon technique.

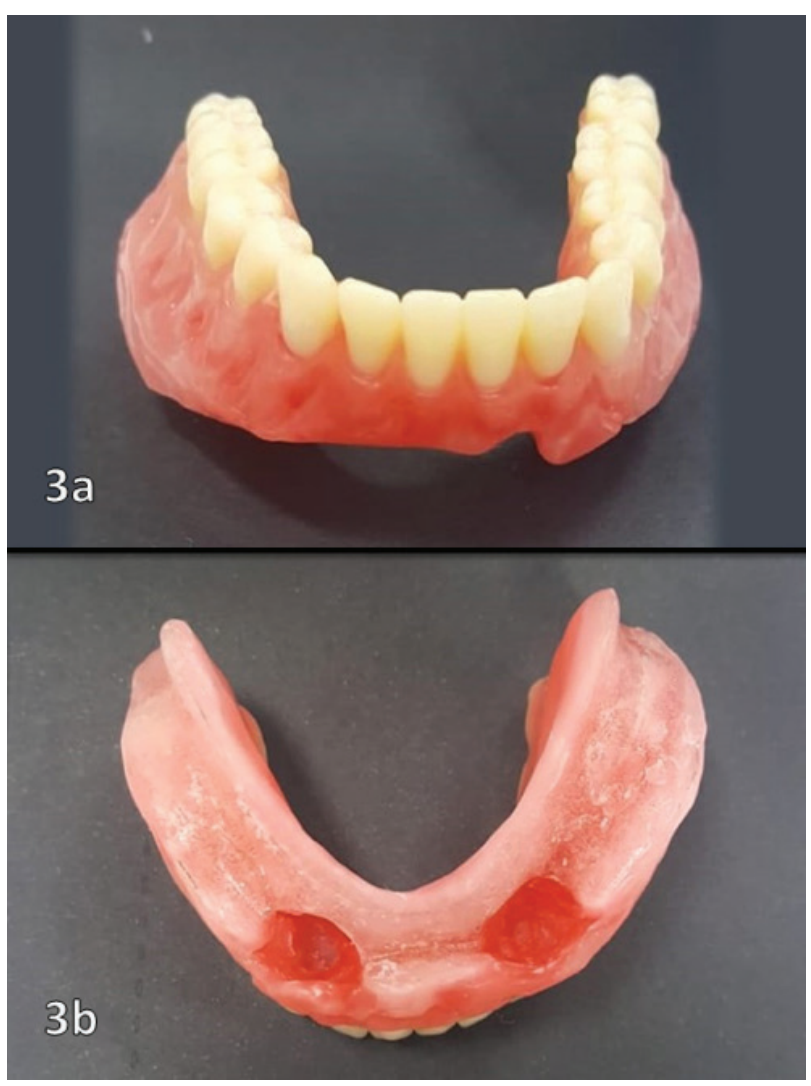

Figure $\mathbf{3}$ - Total acrylic prosthesis. 3b: Reliefs on the inside of the prosthesis.

Afterwards, the cementation of the two intra-radicular posts with zinc phosphate cement (SS White, São Paulo, Brazil) was made and the provisional installation of the new total prosthesis (figures $4 \mathrm{a}$ to $4 \mathrm{~d}$ ), but still without the o'rings fitting, with the intention of not promoting stress on the retainers without first fully setting the cement. 


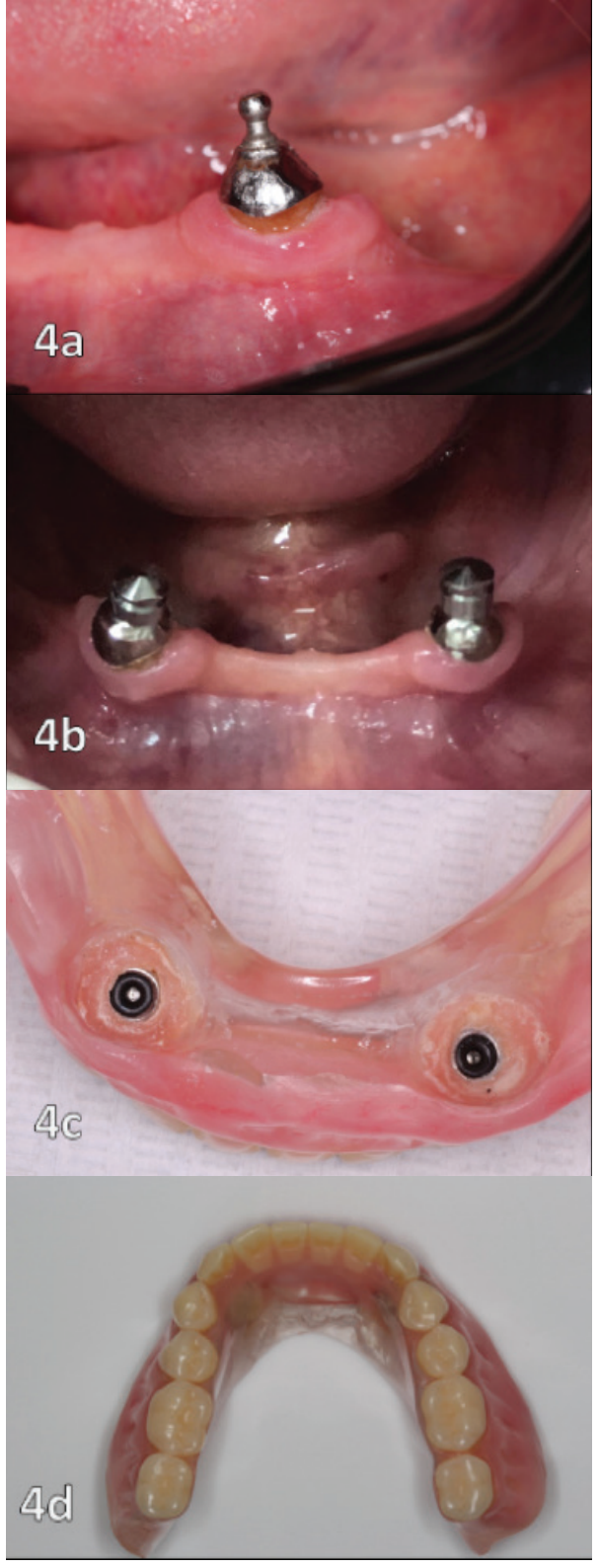

Figure 4 - 4a: Intraradicular retainer installed. 4b: Retention fittings installed over the retainers. 4c: Fittings captured by Nealon technique in the acrylic prosthesis. 4d: Completed prosthesis.

Finally, the overdenture prosthesis was installed as described previously. Occlusal analyzes and adjustments were made using carbon strips on the teeth during maximum intercuspation and extrusive movements, making adjustments in regions that were necessary, such as interferences. Instructions on care and handling of prostheses were given, such as cleaning and maintenance during periods that were not in use, as well as instructions for cleaning the o'rings and dental remnants. Control visits were held once a week for the first three weeks and once every six months, to change the o'rings rubber rings (figures $5 \mathrm{a}$ to 5d).

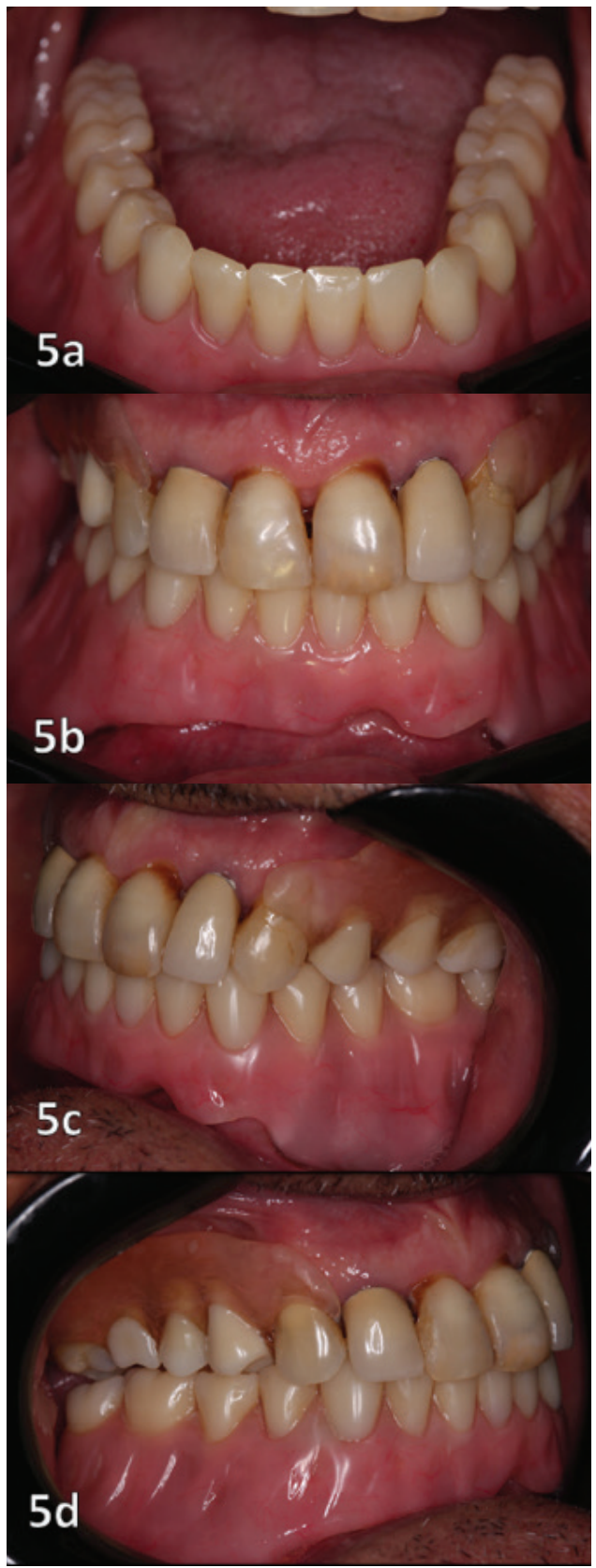

Figure 5 - 5a: Prosthesis installed. 5b-5d: Twelve month followup of the installation of the prosthesis. 


\section{DISCUSSION}

The present article aimed to show an oral rehabilitation alternative in patients underwent to head and neck radiotherapy, with high risk of osteoradionecrosis (ORN), an exacerbated risk if undergoing oral surgery [11].

Considering the frequent difficulty of using lower complete dentures [12,13], different options have emerged with the intention of increasing retention and stability of such prostheses [14]. The advent of dental implants and techniques such as the Branemark Protocol, capable of promoting the rehabilitation of fixed total denture in the jaw, was one of the great milestones of dentistry [15], becoming a reality nowadays clinic for being able to restore function and aesthetics to the patient, with less difficulty in fitting and handling the prosthesis $[16,17]$.

However, the use of dental implants has limitations and specific indications, considering its high value, its initial surgical phase, and because it is directly associated with bone manipulation [14]. One of the main contraindications for dental implants is in patients who underwent radiotherapy treatments due to cancer, especially in the head and neck region, as there is an inherent risk of osteoradionecrosis $[3,11]$.

ORN is a harmful complication resulting from radiation therapy for head and neck cancer. According to the literature [11], jaw ORN is defined as exposed irradiated bone that does not heal for a period of 3 months without any evidence of tumor persistence or recurrence. Its mechanism of pathogenesis is not yet well understood, and it is under investigation, but the main reason is for radiation arteritis that leads to the development of a hypocellular, hypovascular and hypoxic environment, which results in the pathological condition $[18,19]$. Thus, it is highly recommended that all types of treatment performed on such patients do not involve any manipulation of bone tissue [11].

Thus, different oral rehabilitation techniques are preferable, such as the use of full denture overdentures on the teeth, from the use of ball-type attachments on cemented metallic root canal posts after endodontic treatment, which would be able to guarantee a certain level of fixation and stability of the prosthesis, keeping the dental elements in the mouth, avoiding the immediate need for extractions or other surgical procedures [20,21].

In addition to improving the fixation and stabilization of the prosthesis, the permanence and maintenance of the remaining dental elements ensures better levels of proprioception to the patient, considering that there is also a periodontal ligament at work and its ability to promote feedback to the central nervous system, increasing its sensory perception and influencing in the motor control of the masticatory muscles $[22,23]$. The loss of this proprioception can cause less tactile sensitivity and less coordinated masticatory muscle activity, which can create difficulties for food and adaptation [23-25].

The present study demonstrated the effectiveness of the proposed treatment, with a 12-month follow-up in function (figures $5 \mathrm{~b}$ to $5 d$ ), as well as its greater financial viability when compared to dental implant rehabilitation, and its low risk for patients with such conditions.

The overdenture prosthesis, as a removable prosthesis, has some inherent characteristics and limitations, such as the need for removal for cleaning, storage in containers with water and sanitizing solutions at least once a day, and the slight weight that occurs for the non-permanent fixation of the prosthesis during the function. It also presents its inherent risks in the making and maintenance, such as the possibility of carious lesions in the dental remnants, diseases and periodontal alterations, dental fractures and technical and mechanical complications of the prosthetic joint, such as fracture of the prosthesis, retainer retention and loss of the rings. Although evidence shows that, in well-planned and indicated cases, and with adequate maintenance by the patient and dental surgeon, this treatment modality is valid and has a high success rate $[13,21]$. 


\section{CONCLUSIONS}

It was concluded that the option of rehabilitation treatment based on the use of overdenture full dentures on dental remnants in patients who cannot undergo surgical interventions has been shown to be effective for the time evaluated and may be an alternative, with broad patient satisfaction and evidencing a less invasive restorative possibility in cases submitted to radiotherapy for head and neck cancer; however, further studies with a larger number of patients and longer follow-up are needed for better conclusions.

\section{REFERENCES}

1. Ferlay J, Shin HR, Bray F,David Forman, Colin Mathers, Donald Maxwell Parkin. Estimates of worldwide burden of cancer 2008: GLOBOCAN 2008. Int J Cancer. 2010:127:2893-917. doi: 10.1002/jic.25516

2. PaiolaFG, Lopes FC, Mazzi-Chaves JF, Pereira RD, Oliveira HF, Queiroz AM, Souza-Neto MD. How to improve root canal filling in teeth subjected to radiation therapy for cancer. Braz Oral Res. 2018 Nov 29;32:e121. doi:10.1590/18073107bor-2018.vol32.0121

3. Shah JP, Gil Z Current concepts in management of oral cancer surgery. Oral Oncol.2009 Apr-May;45(4-5):394-401. doi:10.1016/j.oraloncology.2008.05.017.

4. Huang SH, OSullivan B. Oral cancer: Current role of radiotherapy and chemotherapy. Med Oral Patol Oral Cir Bucal. 2013 Mar 1;18(2):e233-40.

5. ErikssonD, Stigbrand T.Radiation-induced cell death mechanisms. Tumour Biol. 2010 Aug;31(4):363-72. doi:101007/s13277-010-0042-8

6. Kohli K, Corns R, Vinnakota K, Steiner P, Elith C, Schellenberg D, Kwan W, Karvat A. A bioimpedance analysis of head-and-neck cancer patients undergoing radiotherapy.Curr Oncol. 2018 Jun;25(3):e193-e199. doi:10.3747/c0.25.3920

7. Maio MF. Avaliação dos efeitos da radiação ionizante em materiais utilizados em restauracõoes dentárias. 2009. Dissertação (Mestrado em Tecnologia Nuclear - Aplicações) - Instituto de Pesquisas Energéticas e Nucleares, Universidade de São Paulo, São Paulo, 2009. doi:10.11606/D.85.2009.tde27102009-105515. Acesso em:2019-08-23.

8. Korfage A, Raghoebar GM, Slater JJRH, Roodenburg JLN, Witjes MJH, Vissink A, Reintsema H. Overdentures on primary mandibular implants in pacientes with oral cancer: a follow-up study over 14 years. British Journal of Oral and Maxillofacial Surgery. 2014;52(9):798-805. doi: 10.1016/j.bjoms.2014.05.013

9. Tancu AM, Melescanu Imre M, Preoteasa CT,PreoteasaE. Therapeutical attitudes in tooth supported overdentures with ball attachements. Case report. JMed Life. 2014;7 Spec No. 4(Spec Iss 4):95-8.
10. Bansal S, Aras MA, Chitre V. Tooth Supported Overdenture Retained with Custom Attachments: a Case Report. J Indian Prosthodont Soc. 2014 Dec;14(Suppl 1):283-6. doi: 10.1007/s13191-013-0340-0

11. Chronopoulos A, Zarra T,Ehrenfeld M, Otto S. Osteoradionecrosis of the jaws: definition, epidemiology, staging and clinical and radiological findings. A concise review. IntDent J.2018 Feb;68(1):22-30. doi:10.1111/idj.12318

12. Nassar HI. Patient satisfaction of tooth supported overdentures utilizing ball attachments. Future Dent J. 2016 oct; 2(2):70-3. doi: 10.1016/j.fdj.2016.10.003

13. Kutkut A, Bertoli E, Frazer R, Pinto-Sinai G, Fuentealba Hidalgo R, Studts J. A systematic review of studies comparing conventional complete denture and implant retained overdenture. J Prosthod Res. 2018 Jan:62(1):1-9. doi: 10.1016/. jpor.2017.06

14. Yan Q, HuaF, Shi B.Patients Are More Satisfied With Implant-Supported Mandibular Overdentures Than With Conventional Dentures. J EvidenceBased Dental Practice. 2017 Dec;17(4):411-413. do: 10.1016/j.jebdp.2017.10.010

15. Branemark PI. Osseointegration and its experimental background. The J Prosthetic Dent. 1983 Sep;50(3):399-410. doi:101016/s0022-3913(83)80101-2.

16. Patzelt SBM, Bahat 0 , Reynolds MA, Strub JR. The all-on-four treatment concept:a systematic review. Clin ImplantDent Relat Res. 2014 Dec;16(6):83655. doi: 10.1111/cid.12068

17. Buser D, Sennerby L, De Bruyn H. Modern implant dentistry based on osseointegration: 50 years of progress, current trends and open questions. Periodontology 2000.2017 Feb;73(1):7-21. doi: 10.1111/prd.12185

18. Nabil S, Samman N. Incidence and prevention of osteoradionecrosis after dental extraction in irradiated patients: a systematic review. Int J Oral Maxillofac Surg.2011 Mar;40(3):229-43. doi:10.1016/j.jom.2010.10.005

19. Kuo TJ, Leung CM, Chang HS, Wu CN, Chen WL, Chen GJ, Lai YC, Huang, WC. Jaw osteoradionecrosis and dental extraction after head and neck radiotherapy: A nationwide population-based retrospective study in Taiwan. Oral Oncol. 2016 May;56:71-7. doi: 10.1016/.oraloncology.2016.03.005

20. Schuch C, De Moraes AP, Sarkis-Onofre R, Pereira-Cenci T,Boscato N. An alternative method for the fabrication of a root-supported overdenture: a clinical report. J Prosthetic Dentistry. 2013,109(1),1-4. doi:10.1016/S00223913(13)00013-9

21. Mercouriadis-Howald A, Rollier N, Tada S, McKenna G, Igarashi K, Schimmel M. Loss of natural abutment teeth with cast copings retaining overdentures: a systematic review and meta-analysis. J Prosthod Res. 2018,62(4),407-415. doi: 10.1016/j.jpor.2018.05.002

22. Crum RJ, Loiselle RJ. Oral perception and proprioception: a review of the literature and its significance to prosthodontics.J Prosthetic Dent 1972,28(2), 215-230. doi: 10.1016/0022-3913(72)90141-2

23. Pacer RJ, Bowman DC. Occlusal force discrimination by denture patients. The Journal of Prosthetic Dentistry. 1975,33(6),602-9. J ProsthetDent 1975 Jun;33(6):602-9. doi:10.1016/s0022-3913(75)80120-x

24. Meyer G, Fanghanel J,Proff P.Morphofunctional aspects of dental implants. Annals of Anatomy 0 Anatomischer Anzeiger : Official Organ of the Anatomische Gesellschaft. 2012,194(2), 190-194. doi:10.1016/j aanat.2011.09.006

25. Hsieh WW, Luke A, Alster J, Weiner S. Sensory discrimination of teeth and implant-supported restorations. Int J Oral Maxillofac Implants. 2010;25(1):14652.

Tarcísio José de Arruda Paes Júnior (Corresponding address)

Av. Eng. Francisco José Longo, 777, Jardim São Dimas, 12245000 -

São José dos Campos, SP - Brazil.

Date submitted: 2020 Jan 07

E-mail: tarcisio.paes@unesp.br Accept submission: 2020 May 04 